\title{
Land-cover change in the Tatra Mountains, with a particular focus on vegetation
}

\author{
Jaroslav Solár \& Vladimír Solár
}

Keywords: land-use change, climate change, coniferous forest, Pinus mugo, Carpathians, Slovakia

\section{Abstract}

This paper evaluates land-cover change in the high mountain landscapes of parts of the Tatra Mountains (Western Carpathians, Europe). As well as carrying out a basic analysis of land-cover changes, we compared how these changes related to several abiotic variables and socio-economic influences. We used a geographic information system to analyse aerial images from surveys made in 1955, 1986 and 2010. The areas studied have undergone a number of changes, due most importantly to the establishment of a national park, long-term forestry management, natural disturbances, land abandonment, and the development of tourism. With regard to changes in vegetation cover, it is debatable whether these are related to climate change or to land-use change. Our study revealed two main changes: coniferous forest disturbance, and the expansion of shrubs (Pinus mugo) into the alpine zone. We also observed a slight upward shift of vegetation boundaries for coniferous forest, shrubs and alpine meadows over a period of more than 50 years (1956 to 2010). If we take into consideration (1) that forest ecosystems (and the tree line) have been changed significantly by human influence, and (2) that windstorms provoking outbreaks of spruce bark beetle are not a new phenomenon but more or less periodical in the Tatra Mountains, our results cannot provide clear evidence that climate change is partly responsible for the shift to higher elevations of the boundaries of mountain vegetation.

\section{Profile}

Protected area

Tatra mountain

National Park

Mountain range

Carpathians

Country

Slovakia

\section{Introduction}

Most ecosystems in European mountain areas combine natural components and elements that have been modified by human activity, such as agriculture and forestry (Körner et al. 2005). Altitudinal zones of mountain ecosystems and the biodiversity of these zones represent unique areas for the detection of the effects of climate change (Theurillat \& Guisan 2001; Beniston 2003; Dirnböck et al. 2011), environmental changes (Beniston 2000; Houet et al. 2010), and socioeconomic changes (Bezák \& Mitchley 2013; Gellrich et al. 2007; Griffiths et al. 2013). Knowledge of the interrelationships between these types of change is particularly important for the future development of mountain areas regarding nature and landscape protection, the conservation of biodiversity and the sustainable development of society.

During the last century, worsening agricultural and socio-economic conditions have led to the abandonment of former agricultural areas, especially in marginal mountain areas (Tasser et al. 2007). These socio-economic driving forces, which are part of a current global trend, have also produced spontaneous reforestation of the (abandoned) mountain landscapes in Europe (Mottet et al. 2006; Sitko \& Troll 2008; Kozak 2009; Griffiths et al. 2013). This points to a major transformation in the traditional economy of mountain areas (Kozak 2003), such as a decline in both grazing and forest-management activities, which consequently led to the development of nature conservation and changes in local attitudes to tourism.

In the Carpathians, as in most of Europe, natural tree lines are rare: most are man-made, due to grazing, agriculture and logging; avalanches may also displace treelines (Weisberg et al. 2013). It seems that the Carpathian forests have been and will continue to be driven by the synergetic combination of various factors and trends (Fleischer et al. 2009; Griffiths et al. 2014). According to some authors, windstorms in the High Tatras are periodical (Koreň 2005; Zielonka et al. 2009); they have a long-term effect on the ecosystems of the spruce forests in the foothills (Falt'an et al. 2011). It is important to consider not only individual drivers of change, but also the interacting effects of multiple drivers, including ecological, physiographic and human ones (Kulakowski et al. 2016).

Recent studies carried out in the Tatra Mountains refer to the expansion of Pinus mugo in the alpine zone (Boltižiar 2007; Švajda et al. 2011; Solár \& Janiga 2013), while the coniferous forest area has a general tendency to expand to higher elevations (Mihai et al. 2007; Sitko $\&$ Troll 2008). What produces this shift continues to be widely discussed (Gehrig-Fasel et al. 2007; Jodłowski 2007; Mihai et al. 2007; Palombo at al 2013; Shandra et al. 2013; Weisberg et al. 2013; Kulakowski et al. 2016). A declaration by the Tatra National Park in 1948 led to a regulation of grazing, and in 1954 grazing stopped altogether in the region (Harvan 1965). From several studies of the area (e.g. Boltižiar 2007; Boltižiar \& 


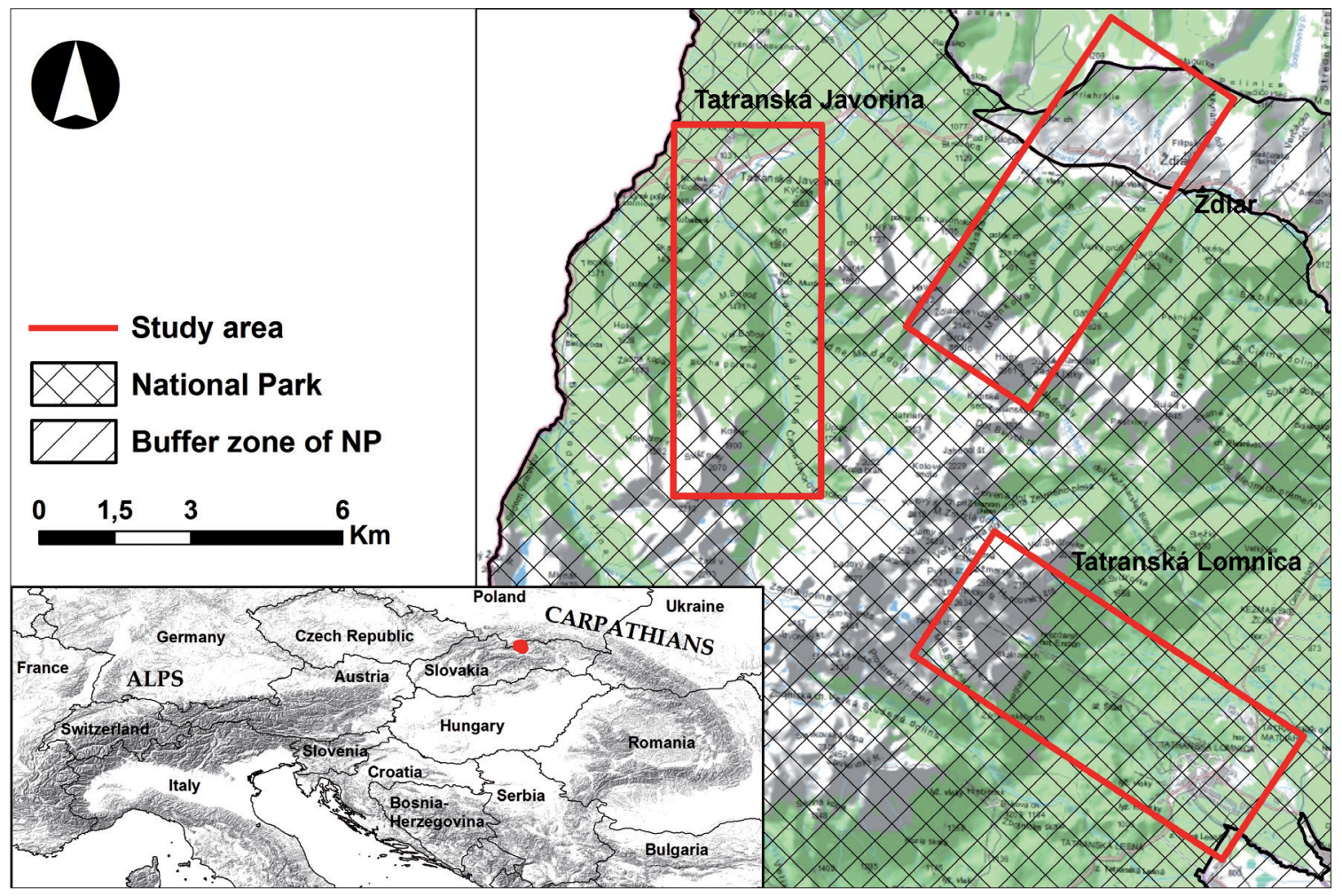

Figure 1 - Selected transects of the landscape in the Tatra Mountains. Data source: Úrad geodéaie, kartografie a katastra SR 2000, c. 035/001004-AG, SVM50.

Olah 2013), we know that land-use change led to the spontaneous reforestation of abandoned agricultural lands, mainly after grazing was restricted (in order to protect nature), but also due to agricultural activities connected with the socialist transition to large-scale farming, during which small parcels were joined into bigger areas, field boundaries disappeared, fields with low productivity were transformed into meadows for hay production, and fields that were narrow or difficult to access by heavy machines were abandoned and excluded from management. At the same time, tourism was actively developed, and local people changed their orientation from agriculture to tourism.

Given increasing temperatures especially in high mountains, we could logically expect mountain ecotone species to migrate to higher elevations, or habitat loss for some animal species. But where changes in the tree line are concerned, globally there is no single pattern to the phenomenon (Harsch et al. 2009). In the case of the Tatra mountains, it is also unclear how environmental factors such as topography, bedrock or water regime can influence vegetation cover change. Therefore, in this study, alongside the basic analysis of land-cover changes, we compared how these changes related to several abiotic variables. We also outline a background of ongoing socio-economic changes, which could have an impact on land-cover changes in the Tatra Mountains. It is debatable whether land-cover changes are related to climate change or to socio-economic development. We consider three main impacts on vegetation in the Tatra Mountains: land abandonment, the development of tourism, and nature protection in association with active forestry management.

\section{Methods}

\section{Study area}

The study area comprises three selected transects of the landscape in the Slovak Tatra Mountains (Tatra National Park, Slovakia), which are situated in the Western Carpathians (Figure 1). The three sections are in the vicinity of the villages Tatranská Javorina (N 49.245448, E 20.139014), Ž diar (N 49.264362, E 20.220458) and Tatranská Lomnica (N 49.179436, E20.254573). Each transect goes from sub-montane to alpine mountain landscape, giving a cross-section from a sub-montane vegetation zone to a sub-nival one (above $2300 \mathrm{~m}$ a.s.l.), but also from an urbanized to an almost natural landscape. The areas were selected in order to take into account different socio-economic influences in the Slovak Tatra Mountains and in order to examine how these different influences have changed land cover, with an emphasis on vegetation cover.

The Javorina area is the least developed (population 219) and least affected by rural depopulation, land abandonment, forestry management and nature protection. Ždiar (population 1382) is a typical upland landscape, where human impact is evident in the mosaic of small parcels given over to different agricultural uses (grazing, crops, meadows). In this area, the main socio-economic forces are urban develop- 
Table 1 - Quality and resolution of data features (aerial im agery).

\begin{tabular}{|l|l|l|l|l|}
\hline Year & Source & Type & $\begin{array}{l}\text { Resolution } \\
\text { [DPI] }\end{array}$ & Format \\
\hline 2010 & Eurosense Slovakia & Orthophoto & RBG 96 & .img \\
\hline 1986 & $\begin{array}{l}\text { Topographical } \\
\text { Institute }\end{array}$ & Aerial photo & Gray 1200 & .tiff \\
\hline 1955 & $\begin{array}{l}\text { Topographical } \\
\text { Institute }\end{array}$ & Aerial photo & Gray 1200 & .tiff \\
\hline
\end{tabular}

ment connected to tourism development (people have changed from their traditional agricultural way of life to the provision of tourism services), land abandonment, forestry management and nature protection. The Lomnica area (Lomnica: population 1304) is the most affected by human activity, mainly due to the development of tourism (ski resorts, cable cars, hotels, spa and other facilities, such as an observatory on Lomnicky peak). Tourism in this area has a long tradition, predating the National Park. As in other areas, the influence of forestry management and nature protection is visible.

The Tatra Mountains rise abruptly from the surrounding lowlands. The highest peak in the study area is Lomnicky (2633.8 $\mathrm{m}$ a.s.l.), which has a total vertical drop of $1834 \mathrm{~m}$. The study area is characterized by high glacio-alpine slopes and glacial relief. The average annual air temperature decreases by $0.6^{\circ} \mathrm{C}$ per $100 \mathrm{~m}$, being 1.6 and $-3.8^{\circ} \mathrm{C}$ at elevations of 1778 and $2635 \mathrm{~m}$, respectively (Konček \& Orlicz 1974). The amount of precipitation increases with elevation, varying from 1.0 to $1.6 \mathrm{~m} \mathrm{yr}^{-1}$ between 1330 and $2635 \mathrm{~m}$, but reaching $>2.00 \mathrm{~m} \mathrm{yr}^{-1}$ in some valleys (Chomitz \& Šamaj 1974). Precipitation is generally higher in the northern part of the mountains than in the southern part, as is runoff, which averages 1.42 and $1.57 \mathrm{~m} \mathrm{yr}^{-1}$ for the south and north, respectively (Lajczak 1996). Snow cover usually lasts from October to June at elevations $>2000 \mathrm{~m}$. At higher elevations, lithic leptosols, leptosols and arenosols are dominant; at lower elevations, rendzic leptosols (rendzinas), cambisols and podzols are dominant (Pelíšek 1973). The potential upper limit of the forest line (coniferous forest - Abies alba, Picea abies, Pinus cembra) is between 1570 and 1650 $\mathrm{m}$; the upper limit of the tree line (Pinus mugo) is at $1800 \mathrm{~m}$ (Futák 1972). The alpine zone (above $1800 \mathrm{~m}$ ) comprises alpine meadows (where species include Festuca picturata, Luqula alpino-pilosa, Calamagrostis villosa and Juncus trifidus), and rocks (bare or covered with lichens commonly Rhizocarpon, Acarospora oxytona and Dermatocarpon luridum) (Vološčuk et al. 1994).

\section{Data collection}

For this study, we used aerial images taken in 1955, 1986 and 2010. Aerial images from 2010 had a reference system (s-jtsk); aerial photographs from 1986 and 1955 (without reference system) were georeferenced using aerial images from 2010 (Table 1). The layers of land cover (1955, 1986 and 2010) were manually digitized using GIS editing tools (ESRI ArcGIS 10), at a scale of approximately 1:1000. CORINE Land Cover (CLC) nomenclature (Heymann et al. 1994) was used to identify land-cover classes. In some cases, interpretation of classes was validated using an in-situ survey. The accuracy of patches (polygon vertex position) was randomly validated in situ using GPS equipment (Trimble Geoxt), and standard deviation was estimated to approximately $2 \mathrm{~m}$. After completing the manual

Table 2 - Basic characteristics of transects with proportion of land cover in the years 1955, 1986 and 2010 (* data from year 1940).

\begin{tabular}{|c|c|c|c|c|c|c|c|c|c|}
\hline & \multicolumn{3}{|c|}{ T. Javorina } & \multicolumn{3}{|c|}{ Ždiar } & \multicolumn{3}{|c|}{ T. Lomnica } \\
\hline & 1955 & 1986 & 2010 & 1955 & 1986 & 2010 & 1955 & 1986 & 2010 \\
\hline Total area & \multicolumn{3}{|c|}{$3909 \mathrm{ha}$} & \multicolumn{3}{|c|}{$3909 \mathrm{ha}$} & \multicolumn{3}{|c|}{$3909 \mathrm{ha}$} \\
\hline Elevation range & \multicolumn{3}{|c|}{ 950-2200 m. a.s.I. } & \multicolumn{3}{|c|}{ 900-2 150 m. a.s.l. } & \multicolumn{3}{|c|}{$800-2600$ m. a.s.l. } \\
\hline Population & $384^{*}$ & - & 220 & $2011^{*}$ & 1768 & 1376 & $1132^{*}$ & - & 1389 \\
\hline Discontinuous urban fabric & 0.05 & 0.08 & 0.09 & 0.18 & 0.27 & 0.33 & 0.20 & 0.42 & 0.49 \\
\hline Industrial or commercial units & 0.03 & 0.04 & 0.04 & 0.00 & 0.00 & 0.00 & 0.04 & 0.24 & 0.25 \\
\hline Road and rail networks & 0.47 & 0.52 & 0.62 & 0.33 & 0.51 & 0.68 & 0.97 & 1.37 & 1.47 \\
\hline Green urban areas & 0.06 & 0.18 & 0.19 & 0.29 & 0.35 & 0.36 & 1.84 & 2.71 & 3.16 \\
\hline Sport and leisure facilities & 0.00 & 0.01 & 0.01 & 0.00 & 0.00 & 0.00 & 0.11 & 0.49 & 0.48 \\
\hline Non-irrigated arable land & & & - & & & & 0.03 & 0.03 & 0.03 \\
\hline Pastures and grassland & 11.03 & 5.35 & 4.61 & 7.72 & 22.74 & 19.93 & 3.17 & 2.06 & 1.13 \\
\hline Complex cultivation patterns & 0.17 & 0.20 & 0.20 & 21.68 & 2.84 & 2.46 & 0.42 & 0.40 & 0.39 \\
\hline Broad-leaved forest & 0.17 & 0.19 & 0.26 & 0.09 & 0.18 & 0.46 & 0.32 & 0.43 & 0.32 \\
\hline Coniferous forest & 53.21 & 53.03 & 49.87 & 35.07 & 39.33 & 38.74 & 53.78 & 53.84 & 22.44 \\
\hline Mixed forest & 9.93 & 12.53 & 15.37 & 3.23 & 3.89 & 4.95 & 2.79 & 3.04 & 3.44 \\
\hline Alpine meadows & 9.06 & 8.09 & 7.64 & 21.26 & 19.50 & 17.81 & 3.18 & 2.70 & 2.22 \\
\hline Shrubs - Pinus mugo & 7.41 & 7.79 & 8.07 & 4.03 & 4.76 & 5.72 & 10.13 & 10.70 & 11.04 \\
\hline Damaged forest & 4.51 & 8.09 & 9.16 & 1.99 & 1.48 & 4.33 & 1.95 & 0.79 & 31.11 \\
\hline Bare rock & 3.04 & 3.02 & 3.01 & 3.73 & 3.75 & 3.84 & 20.70 & 20.45 & 21.64 \\
\hline Water courses & 0.84 & 0.84 & 0.84 & 0.39 & 0.38 & 0.38 & 0.26 & 0.26 & 0.26 \\
\hline Water bodies & 0.03 & 0.03 & 0.03 & 0.00 & 0.00 & 0.00 & 0.08 & 0.07 & 0.12 \\
\hline Total & 100.00 & 100.00 & 100.00 & 100.00 & 100.00 & 100.00 & 100.00 & 100.00 & 100.00 \\
\hline
\end{tabular}


Table 3 - Factor loadings of the variables in the area of Javorina (elevation, slope, flow accumulation, solar radiation, Broad-leaved forest, Coniferous forest, Mixed forest, Alpine meadows, Shrubs (Pinus mugo), Damaged forest). PCA analysis, based on correlations; italic $=$ bigher positive coefficients of the principal components; bold = higher negative coefficients of the principal components.

\begin{tabular}{|c|c|c|c|c|c|c|c|c|c|c|}
\hline & \multicolumn{5}{|c|}{ 1955-1986 } & \multicolumn{5}{|c|}{ 1986-2010 } \\
\hline & PC1 & PC2 & PC3 & PC4 & PC5 & PC1 & PC2 & PC3 & PC4 & PC5 \\
\hline Elevation & 0.16 & -0.61 & 0.33 & -0.19 & -0.06 & 0.26 & -0.47 & 0.45 & -0.01 & -0.04 \\
\hline Slope & -0.24 & 0.49 & -0.59 & -0.15 & 0.01 & -0.22 & 0.36 & -0.66 & 0.16 & -0.02 \\
\hline Flow & -0.12 & 0.11 & -0.16 & -0.24 & 0.64 & -0.02 & 0.10 & -0.20 & 0.68 & 0.15 \\
\hline Radiation & 0.00 & 0.30 & -0.58 & -0.01 & -0.15 & -0.17 & 0.17 & -0.59 & -0.22 & -0.03 \\
\hline Broad-leaved forest & -0.02 & 0.08 & -0.11 & -0.07 & -0.74 & -0.05 & 0.03 & -0.08 & -0.14 & -0.93 \\
\hline Coniferous forest & -0.90 & -0.17 & 0.04 & -0.26 & -0.04 & -0.86 & -0.22 & 0.21 & 0.29 & -0.09 \\
\hline Mixed forest & -0.18 & 0.09 & 0.01 & 0.93 & 0.09 & -0.41 & 0.04 & -0.07 & -0.63 & 0.33 \\
\hline Alpine meadows & -0.03 & 0.69 & 0.53 & -0.03 & -0.03 & -0.05 & 0.80 & 0.40 & -0.02 & -0.01 \\
\hline Shrubs (Pinus mugo) & 0.13 & -0.62 & -0.57 & 0.13 & 0.02 & 0.09 & -0.78 & -0.43 & -0.02 & 0.02 \\
\hline Damaged forest & 0.91 & 0.21 & -0.10 & -0.13 & 0.05 & 0.95 & 0.18 & -0.18 & 0.00 & 0.01 \\
\hline Eigenval. & 1.78 & 1.66 & 1.45 & 1.08 & 1.01 & 1.98 & 1.72 & 1.46 & 1.03 & 1.00 \\
\hline Total var. & 17.78 & 16.64 & 14.48 & 10.84 & 10.05 & 19.79 & 17.21 & 14.61 & 10.34 & 10.02 \\
\hline
\end{tabular}
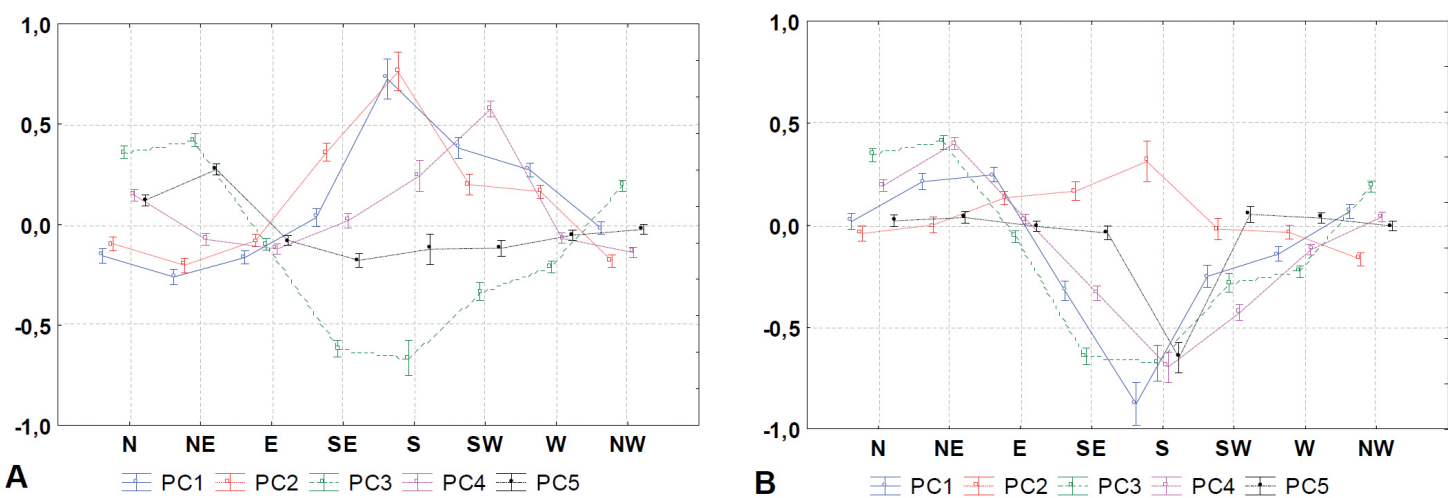

Figure 2 - Aspect and factor loadings of cases from PCA analysis of the Javorina area (based on One-way MANOVA). A: LS means in 1955-1986, Wilks's lambda $=0.77808, F(42,162400)=212.48, p=0.0001) ; B-L S$ means in 1986-2010, Wilks's lambda $=0.80522, \mathrm{~F}(42,162400)=182.78, p=0.0001$.

digitization, we obtained land-cover change results (see Table 1). The layers of land cover were plotted to a grid layer $(25 \mathrm{~m}$ x $25 \mathrm{~m}$ ) of abiotic conditions. Each square of the grid layer contained information about abiotic variables: elevation (m a.s.l.), slope (degree), aspect (degree), solar radiation $\left(\mathrm{WH} / \mathrm{m}^{2}\right.$ ) and flow accumulation (potential surface precipitation build-up). Consequently, after joining these layers spatially, we were able calculate increases or decreases of land-cover classes between years for each square in the grid layer.

\section{Statistical analysis}

For the statistical analysis, Statistica 8 (StatSoft, USA) was used. All variables were standardized. A Mann-Whitney $U$ test was used to compare the medians of the abiotic variables, proportions of land-cover classes, and changes (decrease / increase) of land-cover classes in the Javorina, Ždiar and Lomnica areas. A principal component analysis (PCA)-correlation matrix, a multivariate technique, was used to establish the potential relationships between the variables studied. Principal components are linear combinations of original variables. Integration of the variables enabled us to follow different phenomena that are more or less dependent on each other. The variables studied using PCA were: broad-leaved forest, coniferous forest, mixed forest, alpine meadows, shrubs (Pinus mugo), damaged forest, elevation, slope, flow accumulation and radiation (see Tables 3, 4 and 5). Principal components with an Eigen value greater than 1.0 were evaluated in the results, and factor coordinates of all cases were tested with MANOVA to reveal the effect of aspect and geology. We expected the results to show some evidence of interaction on the borders of their occurrence between various classes of land cover such as coniferous forest, shrubs and alpine meadows. Therefore, we additionally created distribution graphs for increases and decreases of coniferous forest, alpine meadows and shrubs in relation to elevation.

\section{Results}

Land-cover changes considering different socio-economic influences

The land-cover change results (Table 2) show that the predominant land-cover classes in the study area as a whole are forests and shrub vegetation along with grassland, mainly as a result of land abandonment and reforestation. Coniferous stands used to make up the largest proportion, but a decrease of the class is vis- 
Table 4 - Factor loadings of the variables in the Ždiar area (elevation, slope, flow accumulation, solar radiation, Broad-leaved forest, Coniferous forest, Mixed forest, Alpine meadows, Shrubs (Pinus mugo), Damaged forest). PCA analysis, based on correlations; italic $=$ higher positive coefficients of the principal components; bold $=$ higher negative coefficients of the principal components.

\begin{tabular}{|l|r|r|r|r|r|r|r|r|r|r|}
\cline { 2 - 11 } \multicolumn{1}{c|}{} & \multicolumn{4}{c|}{$1955-1986$} & \multicolumn{4}{|c|}{1 1986-2010 } \\
\cline { 2 - 13 } \multicolumn{1}{c|}{} & PC1 & PC2 & PC3 & PC4 & PC5 & PC1 & PC2 & PC3 & PC4 & PC5 \\
\hline Elevation & 0.18 & 0.64 & 0.31 & 0.06 & 0.02 & 0.48 & -0.28 & 0.49 & -0.13 & $-0,18$ \\
\hline Slope & -0.17 & $-\mathbf{0 . 5 1}$ & $-\mathbf{0 . 5 5}$ & -0.10 & -0.13 & -0.31 & 0.17 & $-\mathbf{0 . 7 0}$ & -0.05 & 0.03 \\
\hline Flow & -0.04 & -0.14 & -0.08 & $-\mathbf{0 . 5 7}$ & 0.66 & -0.08 & 0.07 & -0.14 & 0.58 & $\mathbf{- 0 . 5 4}$ \\
\hline Radiation & -0.19 & -0.14 & $-\mathbf{0 . 6 2}$ & 0.17 & -0.31 & -0.05 & -0.13 & $-\mathbf{0 . 6 5}$ & -0.36 & 0.13 \\
\hline Broad-leaved forest & -0.03 & -0.13 & -0.17 & -0.39 & 0.12 & -0.06 & 0.09 & -0.26 & 0.30 & -0.43 \\
\hline Coniferous forest & $-\mathbf{0 . 9 1}$ & 0.14 & 0.10 & 0.04 & 0.03 & 0.61 & 0.52 & -0.16 & -0.37 & -0.33 \\
\hline Mixed forest & 0.13 & -0.06 & 0.31 & $-\mathbf{0 . 6 5}$ & $-\mathbf{0 . 6 4}$ & 0.31 & 0.41 & -0.04 & 0.52 & 0.62 \\
\hline Alpine meadows & 0.06 & $-\mathbf{0 . 7 2}$ & 0.38 & 0.28 & 0.16 & $-\mathbf{0 . 6 1}$ & 0.60 & 0.30 & -0.07 & 0.01 \\
\hline Shrubs (Pinus mugo) & 0.09 & 0.64 & $-\mathbf{0 . 5 5}$ & -0.05 & 0.10 & 0.51 & $-\mathbf{0 . 6 5}$ & -0.30 & 0.21 & 0.08 \\
\hline Damaged forest & 0.86 & -0.14 & -0.23 & 0.09 & 0.04 & -0.70 & $-\mathbf{0 . 6 5}$ & 0.10 & -0.02 & -0.01 \\
\hline Eigenval. & 1.71 & 1.70 & 1.43 & 1.04 & 1.01 & 1.93 & 1.80 & 1.46 & 1.04 & 1.03 \\
\hline Total var. & 17.08 & 16.96 & 14.28 & 10.36 & 10.06 & 19.33 & 17.97 & 14.59 & 10.36 & 10.26 \\
\hline
\end{tabular}
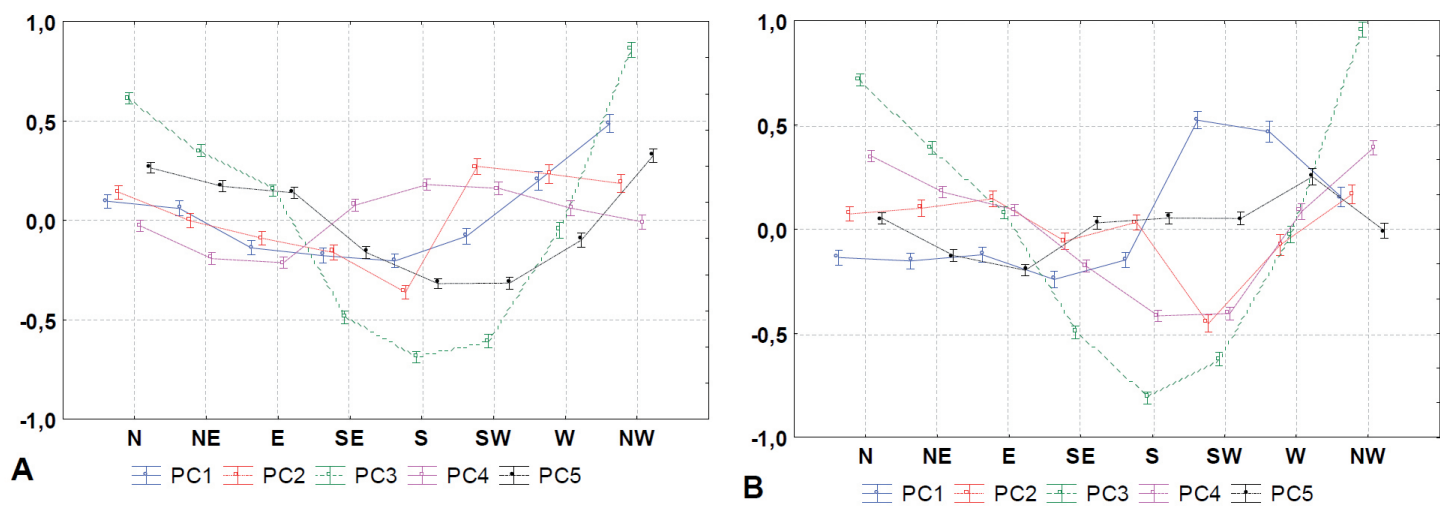

Figure 3 - Aspect and factor loadings of cases from PCA analysis of the Ždiar area (based on One-way MANOVA). A-LS means in 1955-1986, Wilks's lambda $=0.67640, F(42,163100)=337.65, p=0.0001) ; B-L S$ means in 1986-2010, Wilks's lambda $=0.61357, \mathrm{~F}(42,163100)=426.32, p=0.0001$.

ible, mainly in Lomnica, where there was a huge windstorm in 2004. We found scattered patches of damaged forest in all areas and all monitored years. The proportion of mixed forest increased mainly in areas where damaged forest was present in previous periods. The proportion of urban or built-up land also increased (mainly in Lomnica). Grassland (situated at lower altitudes) decreased dramatically due to urban development and forest succession. Alpine meadows decreased due to regeneration of shrubs (Pinus mugo) and succession connected with the abandoning of grazing. The proportion of complex agricultural landuse patterns (agricultural mosaic) decreased, mainly in the Ždiar area, as agricultural land was gradually abandoned and some of it was transformed into grassland (used for hay production).

\section{Locality comparison}

There were significant differences $(p<0.05)$ between all three areas (Javorina, Ždiar and Lomnica) where abiotic variables were concerned. For landcover classes, we observed significant similarities $(p>0.05)$ between the three areas, notably for water elements in Ždiar and Lomnica (in all periods). The median values for broad-leaved forest were similar in Javorina and Ž diar (in 2010), and for mixed forest in Ždiar and Lomnica (in 2010). This could be connected to the new forest-management strategy of replanting damaged forest areas with broad-leaved trees. We also observed significant similarities for the coniferous forest class between Javorina and Lomnica in 1986 and 2010, a result which seems to be related to windstorms (in 1968 and 2004).

We observed no significant differences for the land-cover class shrubs - (Pinus mugo) in Javorina and $\check{Z}$ diar $(p>0,05)$ in the period from 1986 to 2010, or during the same period in Ždiar and Lomnica. We did not observe any significant difference in bare rock, a class which is more or less stable. For land used for agricultural purposes, we observed no significant differences in Javorina and Lomnica in 1968-1986, or for Javorina and Ždiar in 1986-2010. This partly reflects the abandonment of land for agriculture. Table 2 reveals the trend of abandoning agricultural land and a reduction in areas with complex cultivation patterns (small parcels of diverse annual crops and pasture), mainly in Ždiar. People in this traditional upland settlement changed economic strategy from traditional 
Table 5 - Factor loadings of the variables in the Lomnica area (elevation, slope, flow accumulation, solar radiation, Broad-leaved forest, Coniferous forest, Mixed forest, Alpine meadows, Shrubs (Pinus mugo), Damaged forest). PCA analysis, based on correlations; italic $=$ higher positive coefficients of principal components; bold $=$ higher negative coefficients of principal components.

\begin{tabular}{|l|r|r|r|r|r|r|r|r|r|r|}
\cline { 2 - 12 } \multicolumn{1}{c|}{} & \multicolumn{4}{c|}{$1955-1986$} & \multicolumn{5}{|c|}{$\mathbf{1 9 8 6 - 2 0 1 0}$} \\
\cline { 2 - 12 } \multicolumn{1}{c|}{} & PC1 & PC2 & PC3 & PC4 & PC5 & PC1 & PC2 & PC3 & PC4 & PC5 \\
\hline Elevation & $-\mathbf{0 . 5 3}$ & -0.11 & 0.66 & 0.00 & 0.01 & 0.75 & -0.04 & 0.14 & 0.14 & -0.09 \\
\hline Slope & 0.45 & 0.12 & $-\mathbf{0 . 6 6}$ & -0.03 & -0.03 & $-\mathbf{0 . 6 9}$ & 0.07 & -0.09 & -0.07 & -0.02 \\
\hline Flow & 0.06 & 0.05 & -0.19 & -0.09 & 0.85 & -0.12 & 0.02 & 0.43 & -0.23 & 0.32 \\
\hline Radiation & 0.21 & 0.06 & -0.37 & -0.17 & -0.32 & -0.22 & 0.06 & -0.41 & $-\mathbf{0 . 6 3}$ & 0.49 \\
\hline Broad-leaved forest & 0.04 & 0.02 & -0.06 & 0.70 & 0.31 & 0.05 & -0.01 & 0.12 & 0.54 & 0.80 \\
\hline Coniferous forest & 0.24 & $-\mathbf{0 . 9 0}$ & 0.03 & 0.00 & 0.02 & 0.89 & -0.13 & -0.08 & -0.24 & 0.07 \\
\hline Mixed forest & 0.05 & 0.01 & -0.08 & 0.70 & -0.27 & -0.04 & 0.00 & $-\mathbf{0 . 7 7}$ & 0.39 & -0.01 \\
\hline Alpine meadows & 0.79 & 0.21 & 0.47 & 0.00 & 0.02 & -0.20 & $-\mathbf{0 . 8 3}$ & 0.02 & 0.03 & -0.02 \\
\hline Shrubs (Pinus mugo) & $-\mathbf{0 . 8 0}$ & -0.18 & $-\mathbf{0 . 4 7}$ & 0.00 & -0.02 & 0.17 & 0.84 & 0.01 & 0.05 & -0.03 \\
\hline Damaged forest & -0.25 & 0.89 & 0.04 & 0.01 & -0.02 & $-\mathbf{0 . 8 9}$ & 0.11 & 0.19 & 0.14 & -0.12 \\
\hline Eigenval. & 1.90 & 1.71 & 1.50 & 1.02 & 1.00 & 2.75 & 1.43 & 1.03 & 1.01 & 1.00 \\
\hline Total var. & 19.04 & 17.08 & 15.00 & 10.19 & 9.98 & 27.54 & 14.32 & 10.34 & 10.07 & 10.05 \\
\hline
\end{tabular}
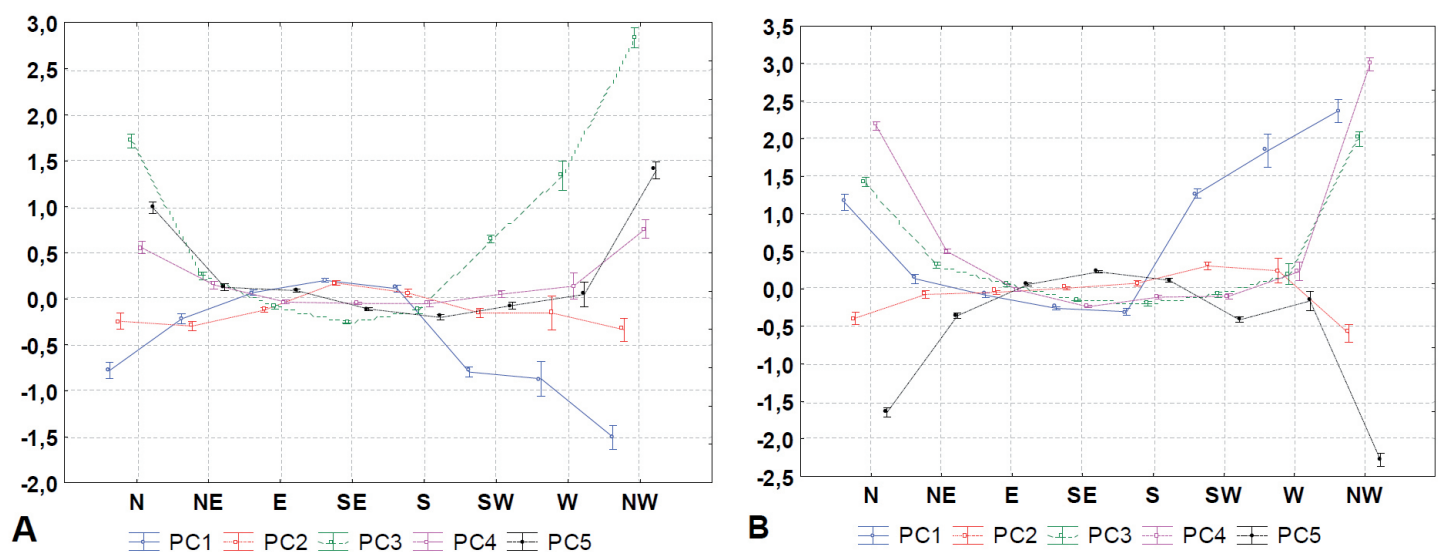

Figure 4 - Aspect and factor loadings of cases from PCA analysis of the Lomnica area (based on One-way MANOVA). A-LS means in 1955-1986, Wilks's lambda $=0.65620, F(42,163300)=365.32, p=0.0001) ; B-L S$ means in 1986-2010, Wilks's lambda $=0.36413, \mathrm{~F}(42,163300)=934.27, p=0.0001$.

agriculture to tourism (for example, providing tourist accommodation), and small-scale farming declined under socialism.

Changes in relation to selected abiotic variables

In the area of Javorina, the most significant change is a decrease of coniferous forest (Principal Component 1 [PC1]; see Table 3 and Figure 2), together with an increase of damaged forest, mainly on the southfacing slopes during the periods 1955-1986 and 19862010. The second and third most significant changes concerned the relative proportions of alpine meadows (PC2) and shrubs (Pinus mugo) (PC3) (see Table 3 and Figure 2), especially on the south- and southwest-facing slopes, namely increases in the number of shrubs at sites with higher elevations, lower degree of slope and lower solar radiation, and at sites with lower elevations where radiation and slope degree are higher. The fourth and fifth changes concern mixed (PC4) and broad-leaved forests (PC5) in relation to the dry habitats of south-facing slopes (see Table 3 and Figure 2).

In the area of Żdiar, the first factor (PC1, Table 4) represents a decrease of coniferous forests associated with an increase of damaged forest. But this fac- tor is more affected by elevation in the second period (1968-2010). At higher sites, we observe increases in the extent of coniferous forests and shrubs, especially on gentle southwestern and western slopes (Figure $3 \mathrm{~A}, \mathrm{~B})$. At lower altitudes, we see increases in alpine meadows and damaged forest. For the first period, the second factor (PC2) clearly shows increases in shrubs (Pinus mugo) and decreases of alpine meadows at sites with higher elevation and lower degree of slope. In the second period, PC2 shows increases in shrubs in relation to decreases in coniferous forest. As in the area of Javorina, PC3 describes increases in shrubs in relation to higher radiation and slopes at lower elevations, especially for the first period (1955-1986). PC4 describes the proportion of mixed forests to wet habitats, and PC5 the proportion of mixed forests to dry habitats.

The situations in the Lomnica area (Table 5) were quite different between the first and second periods. In the first period, the increase in shrubs (Pinus mugo), with a total variance of $19 \%$, was markedly greater than the decrease in coniferous forest. PC1 describes increases in shrubs at sites with higher elevations and gentler slopes (mainly southwest-, west-, northwestand north-facing); PC3 describes increases in shrubs at 


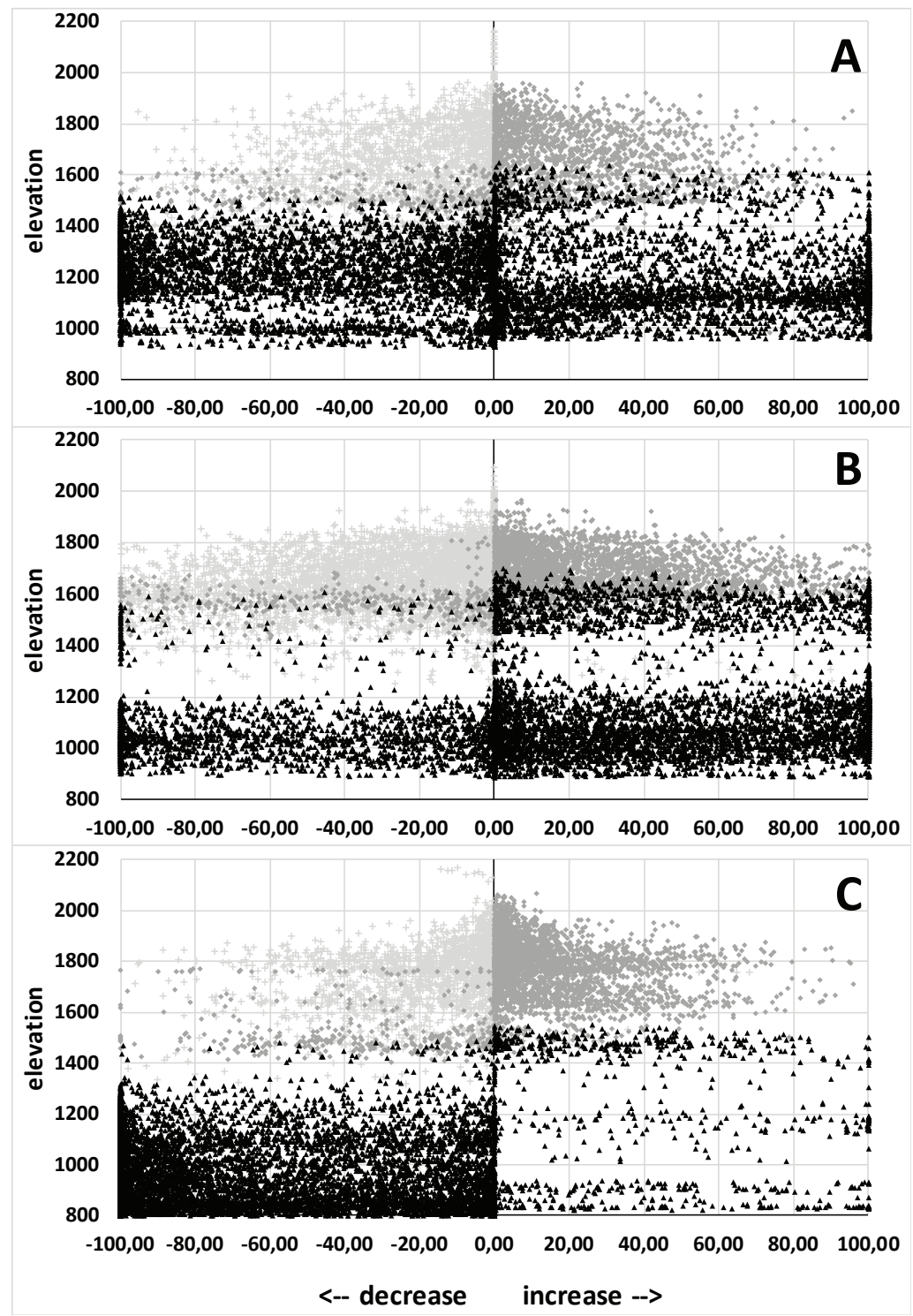

Figure 5 - Scatterplots of increases/ decreases (1955-2010) of land-cover classes (in \% for each square) in relation to elevation (m. a.s.l.): black - coniferous forest; grey - shrubs (Pinus mugo); light grey - alpine meadows. A - Javorina; B - Ždiar; C-Lomnica.

sites with lower elevations and on steeper slopes with southwest, west, northwest and north aspects (Figure 4A, B). The decreases of coniferous forests (PC2) were independent of other variables. PC4 represents the relationship between broad-leaved and mixed forests, and PC5 their relationship to wet habitats.

In the second period, PC1 describes decreases in the extent of coniferous forests (with a total variance of $27.5 \%$ ), which have a strong association with lower elevation and steeper slopes with southwest, west, northwest and north aspects (aspects corresponding to the prevailing windstorm direction in 2004). PC2 represents increases in shrubs (Pinus mugo) more or less independently of other variables. PC3 is characterized by decreases of mixed forests in wet and less sunny habitats, notably due to the windstorm, which uprooted coniferous trees in particular. PC4 describes the relationship between broad-leaved and mixed for- ests and dry, less sunny habitats. PC5 refers to increases of broad-leaved forests in sunny wet habitats.

\section{Shift of the vegetation boundaries}

Figure 5 represents the increase/decrease of coniferous forests, alpine meadows and shrubs (Pinus mugo) at the limits of their occurrence in relation to elevation. The increases of shrubs (right-hand side) corresponded with decreases of alpine meadows (lefthand side). Generally, shrub cover increased at higher elevations, (1) dominantly on sunny and less steep slopes, and (2) at lower elevations on sunny and steeper slopes (according to the PCA in Tables 3, 4 and 5). The decreases of shrubs at lower elevations may be evidence of coniferous forest spreading to higher altitudes, but none of the selected abiotic variables explain this change. 


\section{Discussion}

The results show a slight upward shift of vegetation boundaries from 1956 to 2012. The most significant shift concerned shrubs (Pinus mugo). The expansion of shrubs confirms the findings of several studies in the Western (Švajda et al. 2011) and Eastern Tatra Mountains (Boltižiar 2007; Solár \& Janiga 2013) - that the visible expansion of Pinus mugo to higher elevations is due to the abandonment of traditional land use, but also to better temperature conditions (longer growing seasons, milder winters and shorter periods of snow cover) with enough water. Barbeito et al. (2012) have pointed out that snowmelt date and elevation were the most important environmental factors influencing the survival and growth of Larix decidua, Pinus mugo and Pinus cembra over the entire period studied (30 years). Kaczka et al. (2015) noticed that a reduction of avalanche activity caused by climate warming helps to increase the forested area at the timber line in the Tatra Mountains. Similarly, Hagedorn et al. (2014) summarized that the milder winters with less snow, probably in combination with higher summer temperatures and longer vegetation periods, contributed to changes of the forest-tundra ecotone in the Ural mountains. In our study, this trend could be connected to warming in the Tatra Mountains, where summer and winter temperatures have risen over the last 50 years (Melo 2005; Żmudzka 2011; Melo et al. 2013). On the other hand, the historical human effect on vegetation in the Tatra Mountains greatly limits attempts to identify changes that are due solely to climate change. According to some historical sources (e.g. Plesník 1978), the forest tree line used to be considerably lower due to grazing (especially in the Belianske Tatras, locality Ždiar) - by $200 \mathrm{~m}$ on average, and in some places by $350-400 \mathrm{~m}$ or more. Therefore, our results cannot be considered as clear evidence that climate change is responsible for shifting mountain vegetation boundaries to higher elevations. We believe that the declaration of the National Park (1948) and the consequent grazing prohibition (1954) were the main driving forces of these changes in the Tatra Mountains. Jodłowski (2007) describes how establishing national parks in the Babia Góra and Giant Mountains enabled secondary succession, which has led to the colonization of previously abandoned habitats. Similar findings have been observed in the Alps (e.g. Cocca et al. 2012) and the Pyrenees (e.g. Améztegui et al. 2010). Recently, Tasser et al. (2017) have observed that land-use change is responsible for land-cover change (especially as secondary succession), but in cases of extreme land abandonment or climate change, land use and climate change would have similar effects. Today's vegetation is strongly determined by current land use (Tasser \& Tappeiner 2002), but the role of climatic warming cannot be ruled out given that land-use transformation obscures the possible effects on plant community structure (Chauchard et al. 2010; Geantă et al. 2014).
Two changes were dominant in our study area: (1) coniferous forest disturbance; (2) the expansion of shrubs (Pinus mugo) in the montane/subalpine belt. The present forest ecosystems continue to be significantly influenced by human activity, mainly forestry management (Fleischer et al. 2009). Many abandoned or damaged areas were afforested by coniferous trees (dominantly by Picea abies) from the $19^{\text {th }}$ century onwards. The declaration of the National Park has raised many questions about the future management of forests and conservation, but when the park was established little was known about the possible effects of climate change.

Before the huge windstorm in 2004, the health of the mountain forests in Tatra National Park, was already declining (Koreň et al. 1993). The health status of the coniferous forest seems to be influenced by various factors, including habitat conditions such as elevation, slope and soil properties (Koreň et al. 1993), and climatic conditions such as temperature (Büntgen et al. 2007), precipitation (Holko et al. 2009) and wind (Zielonka et al. 2010), together with other negative factors such as insufficiently differentiated stand structure, inadequate forest management, air pollution, acidification, photo-oxidants and heavy metals (Fleischer \& Koreň 1995; Grodzińska \& SzarekLukaszewska 1997; Fleischer et al. 2009; Moravčík et al. 2012). The synergies between various stressors create conditions for disturbances. However, periodical windstorms resulting in outbreaks of spruce bark beetle (Mezei et al. 2014) are not a new phenomenon in the Tatra Mountains. Koreň (2005) provides historical data about severe windthrows affecting the Tatra Mountains (mainly in the southern part); Zielonka et al. (2009) provide evidence of coniferous forest disturbance at the end of the $18^{\text {th }}$ century recorded in the tree-rings of the oldest spruce and larch specimens.

The situation in the subalpine zone, where spruce forests have semi-open canopies (Szewczyk et al. 2011), could be different. According to the regional monitoring of forest dynamics (based on Landsat), for the period 1985 to 2010 roughly $20 \%$ of the Carpathian forests experienced disturbances of some kind, particularly for conifers (Griffiths et al. 2014; Vatseva et al. 2016). Our results show that damaged forest areas were not situated predominantly in sunny and dry habitats, where we could expect the effects of climate change on the environmental conditions (annual temperature and precipitation) to be particularly noticeable. We must be very prudent in concluding that climate change plays the main role in this case. In our study areas, the situation seems to be influenced mainly by human activity and inadequate forest management, which preferred monocultures of spruce based on non-autochthonous seeds. Furthermore, Kopecka (2011) noticed that the so-called natural Tatra forests (these forests were affected by human activity in the more distant past) before the disastrous windstorm of 2004 did not correspond to natural development at all: 
in species composition and structure, the forests more or less resembled economic forests. Fleischer et al. (2009) expect that further forest development will be driven by a synergetic combination of negative factors and tendencies (impact of pollution, extremely warm weather, windstorms, insect attacks and fires). To limit the negative impact of climate change on the living forest, they suggest an increase in the percentage of broadleaf species, especially maple, due to the poor adaptation ability of spruce and the absence of beech in the whole Tatra Mountain region and foothills. Our results confirm that the proportion of mixed forest has increased in the whole study area.

\section{Conclusions}

Knowledge of continuing land-cover changes and their effects on the relationships between land-cover classes in mountain areas is particularly important for future development regarding nature and landscape protection, the conservation of biodiversity and the sustainable development of society. Using images taken by aerial surveys in 1955, 1986 and 2010, we were able to analyse land-cover changes over a 50 -year period. We then compared how these changes correlated with several abiotic variables and socio-economic influences. The proportion of urban or built-up land has increased, mainly in areas where tourism has developed. Grassland situated at lower altitudes has decreased dramatically due to urban development, land abandonment (resulting in succession) and afforestation. We found scattered patches of damaged forest in all areas and in all monitored years. Mountain meadows have decreased due to succession and the regeneration of shrubs (Pinus mugo). Generally, shrub cover has increased at higher elevations, but most of this increase has been on sunny, steeper slopes at lower elevations.

Two changes were dominant in the study area: coniferous forest disturbance, and shrub expansion in the subalpine zone. We also observed a slight upward shift of the coniferous forests. These trends could be connected to warming in the Tatra Mountains, where summer and winter temperatures have risen during the past 50 years. On the other hand, the historical human impacts on vegetation in the Tatra Mountains greatly limit approaches trying to pinpoint effects that are due specifically to climate change.

More research on vegetation dynamics in Slovakia's mountain areas is needed in light of the significance of vegetation in the context of global change. It is clear that human impact and grazing have never been ubiquitous in the Tatra Mountains. Therefore, it is very important to find places without human influence or past grazing. The highest, most remote and most inaccessible locations will probably be the most suitable places for observing the possible shift of vegetation due to climate change in the Tatra Mountains.

\section{References}

Améztegui, A., L. Brotons \& L. Coll 2010. Landuse changes as major drivers of mountain pine (Pinus uncinata Ram.) expansion in the Pyrenees. Global Ecology and Biogeography 19(5): 632-641. DOI: 10.1111/j.14668238.2010.00550.x

Barbeito, I., M.A. Dawes, C. Rixen, J. Senn \& P. Bebi 2012. Factors driving mortality and growth at treeline: a 30-year experiment of 92000 conifers. Ecology 93: 389-401. DOI: 10.1890/11-0384.1

Beniston, M. 2000. Environmental Change in Mountains and Uplands. New York.

Beniston, M. 2003. Climatic change in mountain regions: a review of possible impacts. Climatic Change 59(1-2): 5-31. DOI: 10.1007/978-94-015-1252-7_2

Bezák, P. \& J. Mitchley 2013. Drivers of change in mountain farming in Slovakia: From socialist collectivisation to the Common Agricultural Policy. Regional Environmental Change 14(4): 1343-1356. DOI: 10.1007/ s10113-013-0580-x

Boltižiar, M. 2007. Structure of High Mountain Landscape of Tatra Mountains. Largescale Mapping, Analysis and Evaluation of Changes by Application of Data from Earth Remote Survey. UKF, ÚKE, SAV, Nitra, Slovakia. [In Slovak]

Boltižiar, M. \& B. Olah 2013. Land Use Changes of UNESCO Biosphere Reserves in the Slovak Carpathians Since the Late Eighteenth Century. In: Kozak, J. (ed.), The Carpathians: Integrating Nature and Society Towards Sustainability, Environmental Science and Engineering: 377-391. DOI: 10.1007/978-3-642-127250_27

Büntgen, U., D.C. Frank, R.J. Kaczka, A. Verstege, T. Zwijacz-Kozica \& J. Esper 2007. Growth responses to climate in a multi-species tree-ring network in the Western Carpathian Tatra Mountains, Poland and Slovakia. Tree Physiology 27: 689-702. DOI: 10.1093/ treephys/27.5.689

Chauchard, S., F. Beilhe, N. Denis \& Ch. Carcaillet 2010. An increase in the upper tree-limit of silver fir (Abies alba Mill.) in the Alps since the mid-20 $0^{\text {th }}$ century: A land-use change phenomenon. Forest Ecology and Management 259(8): 1406-1415. DOI: 10.1016/j. foreco.2010.01.009

Chomitz K. \& F. Šamaj 1974. Precipitation characteristics. In: Konček, M., I. Bohuš, V. Briedoň, K. Chomicz, R. Intribus, L. Kňazovický, M. Kolodziejek, M. Kurpelová, G. Murinová, Š. Myczkowski, M. Orlicz, J. Orliczowa, J. Otruba, J. Pacl \& V. Peterka (eds.), Climate of Tatras. Veda, Bratislava, Slovakia. [In Slovak]

Cocca, G., E. Sturaro, L. Gallo \& M. Ramanzin 2012. Is the abandonment of traditional livestock farming systems the main driver of mountain landscape change in Alpine areas?. Land Use Policy 29(4): 878-886. DOI: 10.1016/j.landusepol.2012.01.005

Dirnböck, T., F. Essl \& W. Rabitsch 2011. Disproportional risk for habitat loss of high-altitude endemic species under climate change. Global 
Change Biology 17(2): 990-996. DOI: 10.1111/j.13652486.2010.02266.x

Falt’an, V., M. Bánovský \& M. Blažek 2011. Evaluation of land cover changes after extraordinary windstorm by using the land cover metrics: a case study on the High Tatras foothill. Geografie 116(2):156-171.

Fleischer, P. \& M. Koreñ 1995. Forest health conditions in the Tatra biosphere reseve. Ekológia 14(4): 445-457

Fleischer, P., M. Koreň, J. Škvarenina \& V. Kunca 2009. Risk Assessment of the Tatra Mountains Forest. In: Strelcová, K. (ed.), Bioclimatology and Natural Hazards: 145-154. DOI: 10.1007/978-1-4020-88766_13

Futák, J. 1972. Vegetation. In: Lukniš, M. (ed.), Slovensko 2, Príroda, Obzor. Bratislava, Slovakia. [In Slovak]

Geantă, A., M. Gałka, I. Tanțău, S.M. Hutchinson, M. Mîndrescu \& A. Feurdean 2014. High mountain region of the Northern Romanian Carpathians responded sensitively to Holocene climate and land use changes: A multi-proxy analysis. The Holocene 24(8): 944-956. DOI: $10.1177 / 0959683614534747$

Gehrig-Fasel, J., A. Guisan \& N.E. Zimmermann 2007. Tree line shifts in the Swiss Alps: Climate change or land abandonment? Journal of Vegetation Science 18(4): 571-582. DOI: 10.1111/j.1654-1103.2007. tb02571.x

Gellrich, M, P. Baur \& N.E. Zimmermann 2007. Natural forest regrowth as a proxy variable for agricultural land abandonment in the Swiss mountains: A spatial statistical model based on geophysical and socio-economic variables. Environmental Modelling \& Assessment 12(4): 269-278. DOI: 10.1007/s10666-0069062-6

Griffiths, P., T. Kuemmerle, M. Baumann, V.C. Radeloff, I.V. Abrudan, J. Lieskovsky, C. Munteanu, K. Ostapowicz \& P. Hostert 2014. Forest disturbances, forest recovery, and changes in forest types across the Carpathian ecoregion from 1985 to 2010 based on Landsat image composites. Remote Sensing of Environment 151: 72-88. DOI: 10.1016/j.rse.2013.04.022

Griffiths, P., D. Müller, T. Kuemmerle \& P. Hostert 2013. Agricultural land change in the Carpathian ecoregion after the breakdown of socialism and expansion of the European Union. Environmental Research Letters 8(4): 1-12. DOI: 10.1088/17489326/8/4/045024

Grodzińska, K. \& G. Szarek-Łukaszewska 1997. Polish Mountain Forests: Past, Present and Future. Environmental Pollution 98: 369-374. DOI: 10.1016/ S0269-7491(97)00145-0

Hagedorn, F., S.G. Shiyatov, V.S. Mazepa, N.M. Devi, A.A. Grigor'ev, A.A. Bartysh, V.V. Fomin, D.S. Kapralov, M. Terent'ev, H. Bugman, A. Rigling \& P.A. Moiseev 2014. Treeline advances along the Urals mountain range-driven by improved winter conditions? Global change biology 20(11): 3530-3543. DOI: $10.1111 /$ gcb.12613
Harsch, M.A., P.E. Hulme, M.S. McGlone \& R.P. Duncan 2009. Are treelines advancing? A global metaanalysis of treeline response to climate warming. Ecology letters 12(10): 1040-1049. DOI: 10.1111/j.14610248.2009.01355.x

Harvan, L. 1965. How was the gazing solved in the Tatra National Park. Treatises Concerning the Tatra National Park 8: 231-253. [In Slovak]

Heymann, Y., Ch. Steenmans, G. Croissille \& M. Bossard 1994. CORINE land cover. Technical guide. Luxembourg, Office for Official Publications of the European Communities.

Houet, T., T.R. Loveland, L. Hubert-Moy, C. Gaucherel, D. Napton, C.A. Barnes \& K.L. Sayler 2010. Exploring subtle land use and land cover changes: a framework for future landscape studies. Landscape Ecology 25: 249-266 DOI: 10.1007/s10980-009-9362-8

Holko, L., J. Škvarenina, Z. Kostka, M. Frič \& J. Staroň 2009. Impact of spruce forest on rainfall interception and seasonal snow cover evolution in the Western Tatra Mountains, Slovakia. Biologia 64(3): 594 599. DOI: 10.2478/s11756-009-0087-6

Jodłowski, M. 2007. Krummbolz-line in the Tatra Mts. Babia Góra and the Giant Mts. Ecotone Structure and Dynamics. PhD dissertation. Krakow, Poland: Institute of Geography and Spatial Management of the Jagiellonian University.

Kaczka, R.J., M. Lempa, B. Czajka, K. Janecka, Z. Rączkowska, J. Hreško \& G. Bugar 2015. The recent timberline changes in the Tatra Mountains: A case study of the Mengusovská Valley (Slovakia) and the Rybi Potok Valley (Poland). Geographia Polonica 88(2): 71-83. DOI: 10.7163/GPol.0016

Konček, M. \& M. Orlicz 1974. Temperature characteristics. In: Konček, M., I. Bohuš, V. Briedoň, K. Chomicz, R. Intribus, L. Kňazovický, M. Kolodziejek, M. Kurpelová, G. Murinová, Š. Myczkowski, M. Orlicz, J. Orliczowa, J. Otruba, J. Pacl \& V. Peterka (eds.), Climate of Tatras. Veda, Bratislava, Slovakia. [In Slovak].

Kopecka, M. 2011. Destruction of the forest habitat in the Tatra National Park, Slovakia. Biodiversity Loss in a Changing Planet. DOI: 10.5772/24106

Koren, M. 2005. Windfall in the forest of the TANAP, reasons and consequences. Proceedings from seminar: Actual problems in forest conservation. Banská Štiavnica 28-29.04.2005: 46-55. [In Slovak]

Koreň, M., P. Fleischer \& R. Šoltés 1993. Evaluation of monitoring forest health in TANAP 31.12.1992. [Vyhodnotenie monitoring zdravotného stavu lesov TANAP-u k 31.12.1992.] Správa TANAP-u Tatranská Lomnica: 14 \& attachment (unpublished). [In Slovak]

Körner, C., M. Ohsawa, E. Spehn, E. Berge, H. Bugmann, B. Groombridge, L. Hamilton, T. Hofer, J. Ives, N. Jodha, B. Messerli, J. Pratt, M. Price, M. Reasoner, A. Rodgers, J. Thonell \& M. Yoshino 2005. Mountain systems. In: Hassan R., R. Scholes \& N. Ash (eds.), Ecosystems and Human Wellbeing. Current State and Trends: Findings of the Condition and Trends Working Group of the Millennium Ecosystem Assessment. 681-716. 
Kozak, J. 2003. Forest Cover Change in the Western Carpathians in the Past 180 Years. Mountain Research and Development 23(4): 369-375. DOI: 10.1659/0276-4741(2003)023[0369:FCCITW]2.0. $\mathrm{CO} ; 2$

Kozak, J. 2009. Land Use Change in the Northern Carpathians. Alpine space - man \& environment 7: 93-96.

Kulakowski, D., I. Barbeito, A. Casteller, R. Kaczka \& P. Bebi 2016. Not only climate: interacting drivers of treeline change in Europe. Geographia Polonica 89(1): 7-15. DOI: 10.7163/GPol.0042

Lajczak, A. 1996. Hydrology. In: Mirek, Z., Z. Głowaciński, K. Klimek \& H. Piękoś-Mirkowa (eds.), Nature of the Tatra National Park, Tatrzanski Park Narodowy. Zakopane-Krakow, Poland: 169-196. [In Polish]

Melo, M. 2005. Warmer periods in the Slovak mountains according to analogue method and coupled GCM. Croatian Meteorological Journal 40(40): 589-592.

Melo, M., M. Lapin, H. Kapolková, J. Pecho \& A. Kružicová 2013. Climate trends in the Slovak part of the Carpathians. In: Kozak, J., O. Katarzyna, A. Bytnerowicz \& B. Wyżga (eds.), The Carpathians: Integrating Nature and Society Towards Sustainability: 131-150.

Mezei, P., W. Grodzki, M. Blaženec \& R. Jakuš 2014. Factors influencing the wind-bark beetles' disturbance system in the course of an Ips typographus outbreak in the Tatra Mountains. Forest Ecology and Management 312: 67-77. DOI: 10.1016/j.foreco.2013.10.020

Mihai, B., I. Savulescu \& I. Sandric 2007. Change detection analysis 1986-2002 of vegetation cover in Romania. Mountain Research and Development 27(3): 250 258. DOI: $10.1659 /$ mred.0645

Moravč́́k, M., Z. Sarvašová, J. Merganič \& M. Kovalčík 2012. Close to nature management in highmountain forests of Norway spruce vegetation Zone in Slovakia. In: Blanco, J.A. (ed.), Forest Ecosystems-More than Just Trees: 375-414. DOI: 10.5772/31667

Mottet, A., S. Ladet, N. Coqué \& A. Gibon 2006. Agricultural land-use change and its drivers in mountain landscapes: A case study in the Pyrenees. Agriculture, Ecosystems \& Environment 114: 296-310. DOI: 10.1016/j.agee.2005.11.017

Palombo, C., G. Chirici, M. Marchetti \& R. Tognetti 2013. Is land abandonment affecting forest dynamics at high elevation in Mediterranean mountains more than climate change? Plant Biosystems 147(1): 1-11. DOI: $10.1080 / 11263504.2013 .772081$

Pelíšek, J. 1973. Soil conditions in the Tatra National Park. [Pôdne pomery Tatranského národného parku]. Zborník prác o TANAPe 15: 145-180. [In Slovak]

Plesník, P. 1978. Implication of Human Influence in Area of Timber Line and Above in Tatra National Park Territory. Treatises Concerning the Tatra National Park 20: 67-91. [In Slovak]

Shandra, O., P. Weisberg, V. Martazinova, J. Kozak, K. Ostapowicz, A. Bytnerowicz \& B. Wyżga 2013. Influences of Climate and Land Use History on Forest and Timberline Dynamics in the Carpathian Moun- tains During the Twentieth Century. In: Kozak, J., K. Ostapowicz, A. Bytnerowicz \& B. Wyżga (eds.), The Carpathians: Integrating Nature and Society Towards Sustainability: 209-223. DOI: 10.1007/978-3-642-12725-0_16

Sitko, I. \& M. Troll 2008. Timberline Changes in Relation to Summer Farming in the Western Chornohora (Ukrainian Carpathians). Mountain Research and Development 28(3/4): 263-271. DOI: 10.1659/mrd.0963

Solár, J. \&, M. Janiga 2013. Long-term Changes in Dwarf Pine (Pinus mugo) Cover in the High Tatra Mountains, Slovakia. Mountain Research and Development 33(1): 51-62. DOI: 10.1659/MRD-JOURNALD-12-00079.1

Szewczyk, J., J. Szwagrzyk \& E. Muter 2011. Tree growth and disturbance dynamics in old-growth subalpine spruce forests of the Western Carpathians. Canadian journal of forest research 41(5): 938-944. DOI: $10.1139 / \mathrm{x} 11-029$

Švajda, J., J. Solár, M. Janiga \& M. Buliak 2011. Dwarf Pine Pinus mugo and Selected Abiotic Habitat Conditions in the Western Tatra Mountains. Mountain Research and Development 31(3): 220-228. DOI: 10.1659/MRD-JOURNAL-D-09-00032.1

Tasser, E., G. Leitinger \& U. Tappeiner 2017. Climate change versus land-use change - What affects the mountain landscapes more? Land Use Policy 60: 60-72. DOI: 10.1016/j.landusepol.2016.10.019

Tasser, E. \& U. Tappeiner 2002. Impact of land use changes on mountain vegetation. Applied Vegetation Science 5(2): 173-184. DOI: 10.1111/j.1654109X.2002.tb00547.x

Tasser, E., J. Walde, U. Tappeiner, A. Teutsch \& W. Noggler 2007. Land-use changes and natural reforestation in the Eastern Central Alps. Agriculture, Ecosystems \& Environment 118(1-4): 115-129. DOI: 10.1016/j. agee.2006.05.004

Theurillat, J-P. \& A. Guisan 2001. Potential Impact of Climate Change on Vegetation in the European Alps: A Review. Climatic Change 50(1-2): 77-109. DOI: 10.1023/A:101063201

Vatseva, R., M. Kopecka, J. Novacek \& G. Zhelezov 2016. Mapping Forest Fragmentation Based on Morphological Image Analysis of Mountain Regions in Bulgaria and Slovakia. In: Zhelezov, G. (ed.), Sustainable Development in Mountain Regions: Southeastern Europe: 167-181. DOI: 10.1007/978-3-319-20110-8_11

Vološčuk, I., I. Bohuš, E. Bublinec, H. BohušováHradiská, J. Drdoš, Z. Dubravcová, J. Gáer, C. Greguš, J. Haková, B. Chovancová, F. Hindák, M. Janiga, L. Kocián, L. Korbel, M. Koreň, J. Kováč, Z. Kyselová, J. Lazebníček, V. Linkeš, V. Ložek, O. Majzlan, M. Marenčák, R. Midriak, J. Nemčok, V. Novák, J. Olejník, M. Ostrožlík, J. Pacl, L. Paclová, M. Schmidt, F. Smolen, P. Spitzkopf, A. Šoltésová, R. Šoltés \& L. Šomšák 1994. Tatra National Park - Biosphere Reserve. Gradus, Martin, Slovakia. [In Slovak]

Weisberg, P.J., O. Shandra \& M.E. Becker 2013. Landscape Influences on Recent Timberline Shifts in the Carpathian Mountains: Abiotic Influences Modu- 
late Effects of Land-Use Change. Arctic, Antarctic, and Alpine Research 45(3): 404-414. DOI: 10.1657/19384246-45.3.404

Zielonka, T., J. Holeksa, P. Fleischer \& P. Kapusta 2010. A tree-ring reconstruction of wind disturbances in a forest of the Slovakian Tatra Mountains, Western Carpathians. Journal of Vegetation Science 21(1): 31-42. DOI: $10.1111 /$ j.1654-1103.2009.01121.x

Zielonka, T., J. Holeksa, P. Malcher \& P. Fleischer 2009. A two-hundred year history of spruce-larch stand in the Slovakian High Tatras damaged by windstorm in 2004. In: Fleisher, P. \& F. Matejka (eds.), Windfall research in TANAP-2008. Geophysical Institute of the Slovak. Academy of Sciences, Research Station of the TANAP, State Forest of TANAP, Slovakia: 269-274.

Żmudzka, E. 2011. Contemporary climate changes in the high mountain part of the Tatras. Miscellanea
Geographica - Regional Studies on Development 15: 93-102. DOI: $10.2478 /$ v10288-012-0005-6

\section{Authors}

Jaroslav Solár - corresponding author

Institute of High Mountain Biology, University of Zilina, Tatranska Javorina 7, SK-059 56 Slovak Republic.E-mail: solar@uniza.sk

\section{Vladimír Solár}

Department of Geography and Regional Development, Faculty of Humanities and Natural Sciences, University of Presov, 17. novembra 1, SK-081 16 Slovak Republic. E-mail: vladimir.solar@unipo.sk 